ZOOLOGIA 30 (5): 506-512, October, 2013

http://dx.doi.org/10.1590/S1984-46702013000500006

\title{
The relevance of age and nutritional status on the mating competitiveness of medfly males (Diptera: Teprhitidae)
}

\author{
Alzira Kelly Passos Roriz \& lara Sordi Joachim-Bravo ${ }^{1,2}$
}

\author{
${ }^{1}$ Departamento de Biologia Geral, Instituto de Biologia, Universidade Federal da Bahia. Rua Barão do Geremoabo, Campus \\ Universitário de Ondina, 40170-290 Salvador, BA, Brazil. \\ 2 Corresponding author. E-mail: ibravo@ufba.br
}

\begin{abstract}
Results of previous investigations trying to ascertain which physiological factors are more important to the mating success of medfly males are controversial. In part, this controversy owes to the fact that each factor was evaluated by an independent study using different experimental designs and populations. In the present study we compare the roles of age and nutritional status (immature and adult phases) on the mating competitiveness of Ceratitis capitata (Wiedemann, 1824) males. Three parameters were used to evaluate the male mating success: calling behavior (pheromone emission), lek participation and copulation (ability to be chosen by a female). Females gave preference to the males that were given a high protein diet in the larval phase. By contrast, females did not give preference to males that had been well-nourished in the adult phase only. The other parameters evaluated followed the same pattern: young males and males that had been fed a high protein diet during their immature phase had a greater participation in leks and called more often than older males and males that had been fed a diet poor in protein during their larval phase. Therefore, we conclude that the mating success of $C$. capitata males is determined both by age and nourishment during the immature stage.
\end{abstract}

KEY WORDS. Ageing; Ceratitis capitata; fruit fly; nutrition; sexual behavior.

The medfly, Ceratitis capitata (Wiedemann, 1824), is an important crop pest. These flies attack many species of fruits and vegetables of economic importance and cause enormous damage to fruit crops throughout the world (MALAVASI \& ZuCCHI 2000). One important topic when studying economically important species such as the medfly is reproductive behavior. Ceratitis capitata mates in a lek (Prokopy \& Hendrichs 1979, WhitTier et al. 1992), defined as a polygyny system in which males aggregate and enclose a territory for the attraction of females without defending resources (Alcock 2011).

Leks of C. capitata contain from 2 to 10 males and generally form on the leaves of trees, where males call from, while releasing of a sex pheromone by raising the back of their abdomen and everting the membranous portion of their rectal epithelium. Calling is usually accompanied by rhythmic wing beats (Feron 1962, Arita \& Kaneshiro 1989, Sivinsky et al. 2001), which are essential to attract the females to the leks (Alcock 2011). Inside the lek, males dispute preferential sites through agonistic behavior (EBERHARD 1999). When a female arrives, the male initiates a courtship display and then jumps on her in an attempt to copulate. Females evaluates males participating in a lek, and reject most of the courtship displays, leaving before or even after an undesirable male has jumped on her (WhitTiER et al. 1994, WhitTier \& Kaneshiro 1995). It is possible that there are some variables that influence the female's decision, for instance the distance and angle between male and female (BRICEÑo et al. 2007), and tactile stimulation from the male's arista (BRICEÑo \& EBERHARD 2002). It is assumed that the variability of male mating success is determined by female choices (WhiтTiER et al. 1994). Inside the lek, males that perform better in territory disputes and/or courtship behavior are more successful attracting females (NORRY et al. 1999). The better performance of some males with respect to others may reflect the conditions they were subjected to during the immature or adult phases.

Protein intake by C. capitata immatures is essential for larval development, emergence of large adults and egg production (CAngussu \& Zucoloto 1993, 1997, Anjos-Duarte et al. 2011a), because protein is an essential component of all body structures (SLANSKY \& SCRIBER 1985). The effect of protein intake during the immature phase on the sexual success of males has not been directly studied. However several studies have linked the size of the adult to its reproductive success (BLAY \& YUVAL 1997, TAYLOR \& YUVAL 1999).

In order to determine which factors are involved in the mating success of males, it is fundamental to investigate why some males are successful in courting and others are not. Different studies have associated male mating success with protein ingestion (Blay \& Yuval 1997, Papadopoulos et al. 1998, Yuval et al. 2002, MAOR et al. 2004), morphometric traits of the body (Rodriguero et al. 2002), youth (PAPAdopoulos et al. 1998) and 
with certain mating activities such as pheromone emission, lek formation and courtship behavior (NorRy et al. 1999). However, other studies have failed to successfully associate any of these factors with male mating success (ARITA \& KANESHIro 1989, Whittier et al. 1994, Kaspi \& Yuval 2000, Shelly \& KenNelly 2002, SHELLY \& MCInNIS 2003). It is possible that the conflicting results among various studies are due to the fact that different methodologies and and/or fly strains have been used in each, as pointed out by Yuval et al. (2007).

Evaluating the variables that import on the mating success of $C$. capitata males is relevant to the success of the sterile insect technique (SIT) - a pest control method based on the release of large numbers of sterile males in the field to compete for females with wild type males (Briceño et al. 2007). Large quantities of these insects are reared in bio-production facilities (HENDRICHs et al. 1995) and then released. In order to complete with wild males to be chosen by wild females, they must have desirable and adequate physiological and behavioral characteristics.

The present study used a standardized methodology to analyze the influence of age and nutrition of immatures and adults on the mating competitiveness of $C$. capitata males reared in the same laboratory.

\section{MATERIAL AND METHODS}

Flies employed in the experiments were brought from a laboratory lineage with frequent introductions of wild flies (hybrid lineage). This colony had been reared for 12 years at the Laboratório de Ecologia Nutricional de Insetos (LENI) of the Departamento de Biologia Geral do Instituto de Biologia at Universidade Federal da Bahia according to the methodology described by Zucoloto (1987). Males in the immature and adult phases were divided into distinct categories according age and nutritional status for the different experiments (Table I).

In the experiment testing the role of age, we used flies fed a high-protein diet (with $6.5 \mathrm{~g}$ of brewer's yeast as protein source) during the immature and adult phases. In the tests on the effects of nutrition during the immature stage, larvae received diets contained $6.5 \mathrm{~g}$ (high protein) or $3.0 \mathrm{~g}$ (low protein) of brewer's yeast (protein source). To evaluate the influence of adult nutrition, newly-emerged flies received diets contained $6.5 \mathrm{~g}$ of brewer's yeast (protein source), or a diet without this component for 4-5 days. The diet given to all larvae contained sucrose $(11.0 \mathrm{~g})$, citric acid $(1.0 \mathrm{~g})$, nipagin $(1.0 \mathrm{~mL})$, and distilled water $(100.0 \mathrm{~mL})$. All adults also received water and a saturated sugar solution on a daily basis. Adults used in nutritional status experiments had 4-5 days old. All males and females were kept separately in plastic cages $(16 \times 11 \times 10 \mathrm{~cm})$ from emergence to the age required for the studies.

The mate choice tests were performed at the Ondina campus of the Universidade Federal da Bahia, Salvador, state of Bahia, Brazil. Fifty "young" females (4-5 days old), which had been well-nourished in the immature and adult phases (diets with high protein levels), were placed into a screened field cage $(2.30 \times 1.50 \times 2.30 \mathrm{~m})$ with 50 males from each age or nutritional groups confronted: (YM) young males, (OM) old males, (HI) high protein diet in immature phase, (LI) low protein diet in immature phase, (PA) protein diet in adult phase, (WA) without protein diet in adult phase. The cages contained a "pitanga" tree (Eugenia uniflora Linnaeus, $107 \mathrm{~cm}$ tall and with crown diameters of $40 \mathrm{~cm}$ ) on a wooden, $60 \mathrm{~cm}$ high table. Pieces of apple (Malus domestica Linnaeus) were placed on the extremities of some of the tree branches to simulate food resources and oviposition sites. The males from each age or nutritional groups were marked (on their thorax) with different colors (green or blue) using non-toxic paint for identification. The colors were alternated with each experimental repetition. In each experiment, behavioral observations were performed in the morning for a period of 3 hours (starting time 08:00), quantifying copulations and identifying the mated males. After the removal of the copulating pair, a male of the opposite group was also removed from the cage to maintain equal proportions of males from the different categories inside the cage during the experiment (SiLva-Neto et al. 2009).

The copulating couples (as well the males and the females that did not copulate) were captured in test-tubes. Five replicates of each experiment were made. The average temperature during the field experiments was $30 \pm 1^{\circ} \mathrm{C}$ and relative humidity was $80-85 \%$.

The parameters, participation in lek formation and calling behavior, were evaluated in a laboratory cage $(0.68 \times 0.68 \mathrm{x}$ $0.90 \mathrm{~m}$ ) containing a small potted "pitanga" (Eugenia uniflora Linneus) tree, $60 \mathrm{~cm}$ tall and $40 \mathrm{~cm}$ radius. Pieces of apple (Malus domestica Borkhausen) were placed on the tree branches.

Table I. Categories and condition of males used in different experiments of mating success.

\begin{tabular}{lllll}
\hline \multicolumn{1}{c}{ Experiment } & \multicolumn{1}{c}{$\begin{array}{c}\text { Category of males used } \\
\text { in the experiment }\end{array}$} & $\begin{array}{c}\text { Male nutrition } \\
\text { (immature stage) }\end{array}$ & $\begin{array}{c}\text { Male nutrition } \\
\text { (adult stage) }\end{array}$ & $\begin{array}{c}\text { Age on the day of } \\
\text { the experiment }\end{array}$ \\
\hline Age influence on mating success & Young males & High protein diet & High protein diet & $4-5$ days old \\
& Old males & High protein diet & High protein diet & 20 days old \\
Nutrition of Immatures and mating success & High protein ingestion in immature phase & High protein diet & High protein diet & $4-5$ days old \\
& Low protein ingestion in immature phase & Low protein diet & High protein diet & $4-5$ days old \\
Nutrition of Adults and mating success & Protein-diet in adult phase & High protein diet & High protein diet & $4-5$ days old \\
& Diet without protein in adult phase & High protein diet & Diet without protein $4-5$ days old \\
\hline
\end{tabular}


The experiments were performed in the morning hours (starting time 08:00 h) under controlled laboratory conditions (temperature $25 \pm 1{ }^{\circ} \mathrm{C}$, and $70 \%$ relative humidity).

In the tests of lek formation, $20 \mathrm{HI}$ and $20 \mathrm{LI}$ males, previously marked (green or blue), were released into the laboratory cage and observed for 90 minutes, indentifying the lek formations. The same methodology was applied to evaluate the variables age and adult nutrition. When a lek (a grouping of at least two males on the abaxial face of neighboring leaves, according with ARITA \& KANESHIRo (1989) formed, we observed it for one entire minute and then the males involved were collected for later identification. Each experiment had five replicates.

The calling behavior tests followed the same general methodology described above. After the males were released into the cage, we made continuous observations on their pheromone emission for one hour. When pheromone emission was observed (eversion of anal epithelium with the liberation of drop of the hormone) that male was collected for identification. Five replicates were conducted for each test.

We took biometric measurements of half of the males in each experimental procedure, in order to determine body size (according to the methodology described by Zucoloto 1987) and to compare it among males from different test groups. The non-parametric T test was employed to analyze the data, using the GraphPad InStat version 3.00 (GraphPad Software, San Diego California USA). The data was tested for normality using the Kolmogorov and Smirnov test and analyzed for variance homogeneity. When homogeneity of variance was not detected in the groups being compared, we applied the Welch correction to the data; $\alpha=5 \%$ was assumed in all analyses.

\section{RESULTS}

General observations during mate choice tests indicated that most males position themselves on the underside of leaves to release pheromones and to perform their courtship rituals. Most of the copulations occurred on the abaxial surface of a leaf, where lek formation was observed. Only a single male in the lek occupied the leaf at a given time, and when another male landed there, both engaged in territorial disputes.

The young males (YM) mated more frequently: the total copulation average $(\mu)$ was $35.2(70 \%)$, of which young males were responsible for $24.4(69.3 \%)$ and old males for 10.8 $(30.68 \%)(\mathrm{OM})(\mathrm{t}=4.12, \mathrm{p}=0.003)$. The young males were also more frequent in leks: there was an overall average of 26.6 males participating in leks, of which $62.4 \%(\mu=16.6)$ were YM and $37.6 \%(\mu=10) \mathrm{OM}(\mathrm{t}=3.55, \mathrm{p}=0.007)$. In calling behavior experiments we observed a general average of 30.1 males emitting pheromones, of which $64.45 \%(\mu=19.4)$ were YM and $36.54 \%(\mu=11.0) \mathrm{OM}(\mathrm{t}=8.16, \mathrm{p}<0.001)$, (Fig. 1).

The same pattern was found between males that ate a high-protein diet (HI) in the immature phase and those fed a low-protein diet (LI). The HI males had better mating success (Welch's $t=7.07, p=0.002$ ). The overall average of copulations was $30.6(61.2 \%)$, and of these, $94.1 \%(\mu=28.8)$ were HIdiet males and $7.84 \%(\mu=2.4)$ were LI-diet males. The total average of males present in lek formations was $22.4,69 \%(\mu=$ 15.6) HI-diet males and 30.35\% $(\mu=6.8)$ LI-diet males $(t=4.5$, $\mathrm{p}=0.001$ ). In experiments involving calling behavior, the general average number of males emitting pheromone was 25 , of which $71.2 \%(\mu=17.8)$ were HI-diet males and $28.8 \%(\mu=7.2)$ were LI-diet males (Welch's $t=5.77, \mathrm{p}<0.001$ ) (Fig. 2).

The nutritional status of the adult male apparently did not influence the parameters tested. Both groups (PA and WA) had similar mating success $(\mathrm{t}=0.77, \mathrm{p}=0.46)$, lek formation $(\mathrm{t}$ $=0.55, \mathrm{p}=0.60)$ and calling behavior $(\mathrm{t}=1.91, \mathrm{p}=0.09)$ (Fig. $3)$. The average number of copulations was $37.2(74.4 \%)$ and of these, $52.15 \%(\mu=19.4)$ were PA males and $47 \%(\mu=17.8)$ with WA males. In lek formation, the total average of males present in leks was 27.8 , of which $52.5 \%(\mu=14.6)$ were PA males and $48.52 \%(\mu=13.2)$ were WA males. In calling behavior tests, the general average of males emitting pheromones was 32.8: $54.26 \%(\mu=17.8)$ PA males and $45.73 \%(\mu=15.0)$ WA males.

An assessment of the size of males showed that all males that were given a high protein diet in the immature stage, and which were used to test the effects of age and nutritional status on the adult had a similar size: age group $(\mu=2.7, \sigma=0.13$, $\mathrm{p}=0.55)$ and adult nutrition group $(\mu=2.86, \sigma=0.68, \mathrm{p}=$ $0.49)$. However, males given distinct protein concentrations in the immature stage (HI and LI) differed in size: the HI were larger $(\mu=2.9, \sigma=0.74)$ than the $\mathrm{LI}(\mu=2.47, \sigma=0.10)$ (T test, $\alpha=0.05, \mathrm{p}<0.001)$.

\section{DISCUSSION}

Our results indicate that, in C. capitata, young adults and adults that had access to more protein in the immature stage have a greater chance of mating.

Viability indicator models of age-related mate choice predict that females prefer older males because they have already proven that they are able to survive and are able to convey that information in their sexual display (Proulx et al. 2002). However, in the present study, the number of old males that emitted pheromone, participated in lek formation and succeeded in mating was lower than the number of young males engaged in those activities. Thus, the hypothesis that females prefer older males despite their reduced fertilization success or viability of their offspring (Jones 2000, JONES \& ElgAr 2004) does not seem to apply to $C$. capitata, at least when there is a choice between young and old males. The data obtained by us is in agreement with other recent studies on different populations of C. capitata (Silva-Neto et al. 2009, Shelly et al. 2011, Papanastasiou et al. 2011). Working with the same population used in this study, Anjos-Duarte et al. (2011b) had found that 

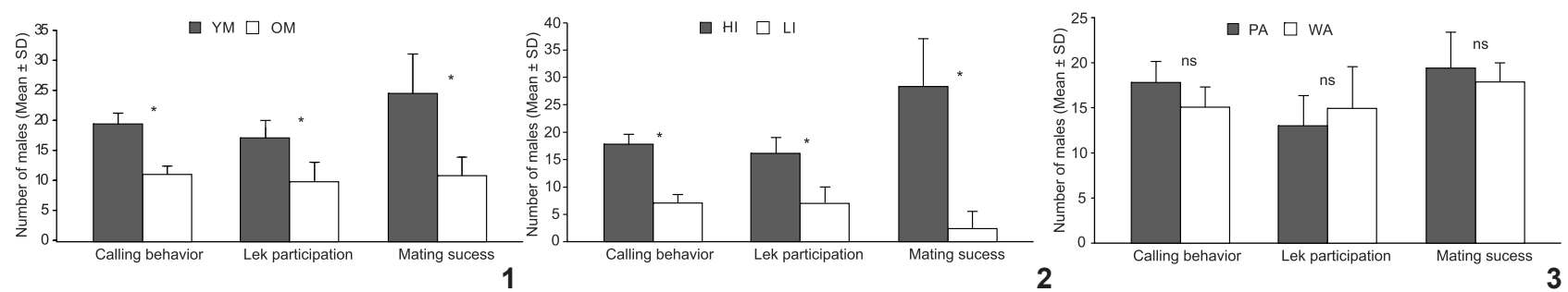

Figures 1-3. Influence of factors, age (1), feeding on the immature phase (2) and feeding in adulthood (3) in the reproductive success of male Ceratitis capitata, assessed by the parameters: the calling behavior (pheromone emission), participation and success in lek mating. The data represent the means and standard deviations of five replicates (experimental cages) for each independent factor and parameter evaluated. Asterisks represent statistical differences between the bars corresponding to the same parameter ( $T$ test with Welch correction $\mathrm{p}<0.05)$, (YM) young males, $(\mathrm{OM})$ old males, $(\mathrm{HI})$ high protein diet in immature phase, (LI) low protein diet in immature phase, (PA) protein diet in adult phase, (WA) without protein diet in adult phase.

females did not distinguish between males of 4 and 12 days of age and accepted to mate equally with both; however, they preferred four or 12 days-old males than 20 days-old ones. Male ageing may affect their courtship ability and/or pheromone production and females apparently are capable of detecting it. For example, longer courtship, as found in 4 day-old males compared to a 20 day-old male in the study of ANJos-DuARTE et al. (2011b), are energetically more costly and may signal to the female that the male is vigorous.

The results of studies on the influence of body size on sexual performance have not been consistent. Different studies have demonstrated that larger males have advantages in terms of sexual performances (CHURCHILl-STANLAND et al. 1986, Blay \& Yuval 1997, TaYlor \& Yuval 1999), whereas others have failed to do so (Whittier et al. 1994, Shelly \& Kennelly 2002). According KASPI et al. (2002) the use of diets with different concentrations of protein and sucrose during the larval stage import on the emission of pheromone by males, but the authors did not investigate the relationship between diet and size. In order to participate in leks, males must insert themselves into them and emit pheromones to attract females. The greater participation of larger males (HI) when compared to smaller (LI) males in these aggregations may be due to the fact that smaller individuals are less competent emitting pheromones and/or disputing territories. Territorial defense is essential to the mating success of medfly males (ARITA \& KANESHIRO 1985). Males dispute territories through agonistic behaviors, using their heads to butt one another until one of them gives up and leaves the site (EBERHARD 1999); larger males (HI) presumably have an advantage during these territorial disputes. Even when large males were put in smaller proportions than the small ones inside a cage, females preferred to mate with the largest males (SiLva-Neto et al. 2012). In addition, females of different sizes (small and large) also preferred to mate with larger males (Anjos-Dunarte et al. 2011a).

Protein ingestion by C. capitata males at the beginning of the adult phase has been positively correlated with their repro- ductive behavior in a number of studies (BLAY \& Yuval 1997, Papadopoulos et al. 1998, TaYlor \& Yuval 1999, Kaspi \& Yuval 2000, Shelly et al. 2002). Perez Staples et al. (2008) studied the addition of a protein source to the diet of Bactrocera tryoni (Froggatt, 1897) males 24 or 48 hours after emergence, finding that it was sufficient to increase the probability that the adult would mate, increase the number of sperm stored, the longevity of the flies and decrease mating latency and female re-mating. Furthermore, eating protein at the beginning of the adult phase has been associated with an improvement in the mating performance of sterile males of B. tryoni (Perez Staples et al. 2009). However, in the present study on C. capitata, we did not find any evidence that the adult diet influences male pheromone emission, lek formation or mating success, corroborating other studies (SHELLY \& Kennelly 2002, Shelly \& McInnis 2003, Joachim-Bravo et al. 2009). The observed similarities in the behavior of males that ingested brewer's yeast in the initial phase of their adult lives and those that did not have access to this protein source may be explained by the fact that they were both already metabolizing protein reserves acquired in their larval phase.

Many holometabolic insects use food resources derived from their larval diets to supplement nutritional deficiencies encountered in their adult phase (BogGs 1981, KarLSSON 1995). Joachim-Bravo et al. (2009) demonstrated that protein intake by C. capitata in the first four days of life did not contribute to increase the mating success of males when compared with those fed on a no-protein diet. Ceratitis capitata males with access to protein resources also emitted more sexual signals and copulated more than males that did not consume proteins (KASPI et al. 2002), which suggests that the proteins may be indispensable to the synthesis of sexual pheromones (BLAY \& Yuval 1997). In the study of Costa et al. (2012), males in the adult phase which were fed protein produced and transferred more sperm to females. In Anastrepha fraterculus (Wiedmann, 1830), the amount of sperm stored in wild females was lower than the amount stored in laboratory females, even though both mated with males fed the same amount of protein as adults (АвRAHAM 
et al. 2012). Flies originating from laboratory rearing receive, during the immature phase, a high-protein diet (Pereira et al. $2009,2010)$, and the resulting adults emerge with a high energy reserve, which is consumed throughout the flies' life (SLANSKY \& SCRIBER 1985). Thus, the protein requirement in early adulthood may be greater if the larval diet is deficient in protein. In the present study, the influence of the nutritional status of the adults was tested with well-nourished flies in the immature phase, which may explain the similarity in the performance of males fed protein or no-protein diets as adults.

The synergistic effects of both nutrition and age cannot be forgotten. Lipid reserves, for example, acquired during the immature phase of C. capitata males are consumed (at least in part) during their sexual activities in the adult phase (WARBURG \& Yuval 1996). Therefore, it is logical to assume that there is a decline in the energy reserves, which is associated with aging, and that can affect male competitiveness. This decline, however, may vary according to the nutrition of the immature and the adult. Comparisons of protein intake during early and middle adult life of lab-reared C. capitata showed that, despite the fact that protein intake during the four first days of the adult life does not import on male mating success, when the period of protein intake is extended to 12 days, males given a protein diet had greater mating success with females and calling than males fed on a no-protein diet at the same period (Silva-Neto et al. 2009). However, being a young male and having been well-nourished in the immature stage are the most important factors in the competition for mating according the present study.

Situations involving competition for females between males of distinct sizes, ages or nutritional histories, presumably occur under natural conditions with wild males. As such, the mass-rearing and release of young and sexually mature males with standardized sizes that are even larger than those encountered in field and that can compete successfully with wild-type males will improve the effectiveness of the sterile insect techniques (SIT) now in use.

\section{ACKNOWLEDGEMENTS}

We acknowledge FAPESB (Foundation of Research of the State of Bahia) for the financial support.

\section{LITERATURE CITED}

Abraham, S.; L. Goane; J. Cladera \& M.T. Vera. 2012. Effects of male nutrition on sperm storage and remating behavior in wild and laboratory Anastrepha fraterculus (Diptera: Tephritidae) females. J. Insect Physiol. 57: 1501-1509.

AlCoK, J. 2011. Comportamento animal. Uma abordagem evolutiva. Porto Alegre, Artmed Editora, XVII+606p.

Anjos-Duarte, C.S.; A.M. Costa \& I.S. Joachim-Bravo. 2011a. Sexual behaviour of the Mediterranean fruit fly (Diptera:
Tephritidae): the influence of female size on mate choice. Journal of Applied Entomology 135: 367-373.

Anjos-Duarte, C.S.; A.M. Costa \& I.S. Joachim-Bravo. 2011b. Influence of female age on variation of mate choice behavior in Mediterranean fruit fly (Diptera: Tephritidae). Journal of Insect Behavior 24: 11-21.

Arita, L.H. \& Y. Kaneshiro. 1985. The dynamics of the lek system and mating success in males of the Mediterranean fruit fly, Ceratitis capitata (Wiedemann). Proceedings Hawaiian Entomological Society 25: 39-48.

Arita, L.H. \& K.Y. Kaneshiro. 1989. Sexual selection and lek behavior in the Mediterranean fruit fly, Ceratitis capitata. Pacific Science 43: 135-143.

BLAY, S. \& B. YuvaL. 1997. Nutritional correlates of reproductive success of male Mediterranean fruit flies (Diptera: Tephritidae). Animal Behavior 54: 59-66.

BogGS, C.L. 1981. Nutritional and life-history determinants of resource allocation in holometabolous insect. America Naturalist 117: 692-709.

BriceÑo, R.D. \& W.G. Eberhad. 2002. Courtship in the medfly, Ceratitis capitata, includes tactile stimulation with the male's aristae. Entomologia Experimentalis et Applicata 102: 221-228.

Briceño, R.D.; W.G. Eberhad; J.C. Vilardi; J.P. Cayol \& T. Shelly. 2007. Courtship behavior of diferent wild strains of Ceratitis Capitata (Diptera: Tephritidae). Florida Entomologist 90: 15-18.

Cangussu, J.A. \& F.S. Zucoloto. 1993. Influence of partial malnutrition on egg production by Ceratitis capitata (Diptera, Tephritidae). Revista Brasileira de Biologia 53 (2): $155-158$.

CAngussu, J.A. \& F.S. Zucoloto. 1997. Effect of protein sources on fecundity, food acceptance and sexual choice by Ceratitis capitata (Diptera: Tephritidae). Revista Brasileira de Biologia 57 (4): 611-618.

Churchill-Stanland, C.; R. Stanland; T.Y. Wong; N. Tanaka; D.O. McInNIs \& R.V. Dowell. 1986. Size as a factor in the mating propensity of Mediterranean fruit flies, Ceratitis capitata (Diptera: Tephritidae), in the laboratory. Journal of Economic Entomology 79: 614-619.

Costa, A.M.; C.S. Anjos-Duarte; A.K.P. Roriz; V.S. Dias \& I.S. JoACHim-Bravo. 2012. Male diet and age influence to inhibit female remating in Ceratitis capitata (Diptera: Tephritidae). Journal of Applied Entomology 136: 456-463.

Eberhard, W.G. 1999. Sexual behavior and sexual selection in the medfly, Ceratitis capitata, p. 459-489. In: M. Aluja \& A. Norrbom (Eds). Fruit Flies (Tephritidae): Phylogeny and Evolution of Behavior. Boca Raton, CRC Press, 963p.

Féron, M. 1962. L'instinct de reproduction chez la mouche Mediterranéenne des fruits (Ceratitis capitata Wiedemann) (Diptera, Tephritidae). Comportement sexuel. Comportement de ponte. Revue de Pathologie Végétale et d'Entomologie Agricole de France 41: 1-129. 
Hendrichs, J.; G. Franz \& P. Rendon. 1995. Increased effectiveness and applicability of the sterile insect technique through maleonly releases for control of mediterranean fruit flies during fruiting seasons. Journal Applied Entomology 119: 371-377.

Joachim-Bravo, I.S.; C.S. Anjos \& A.M. Costa. 2009. The role of protein in the sexual behavior of males of Ceratitis capitata (Diptera: Tephritidae): mating success, copula duration and number of copulations. Zoologia 26 (3): 407-412.

JONES, T.M. 2000. Adaptive female choice for middle-aged mates in a lekking sandfly. Proceedings of the Royal Society of London, Series B, Biological Sciences 267: 681-686.

Jones T.M. \& M.A. Elgar. 2004. The role of male age, sperm age and mating history on fecundity and fertilization success in the hide beetle. Proceedings of the Royal Society of London, Series B, Biological Sciences 271: 1311-1318.

KARLSSON, B. 1995. Resource allocation and mating systems in butterflies. Evolution 49: 955-961.

KaSPI, R. \& B. Yuval. 2000. Post-teneral protein feeding improves sexual competitiveness but reduces longevity of mass reared sterile male Mediterranean fruit flies. Annals of the Entomological Society of America 93: 949-955.

Kaspi, R.; S.Mossinson; T. Drezner; B. Kamensky \& B. Yuval. 2002. Effects of larval diet on development rates and reproductive maturation of male and female Mediterranean fruit flies. Physiological Entomology 27 (1): 29-38.

Malavasi, A \& R.A. Zucchi. 2000. Moscas-das-frutas de importância econômica no Brasil. Conhecimento básico e aplicado. Ribeirão Preto, Holos Editora, 320p.

Maor, M.; B. Kamensky; S. Shloush \& B. Yuval. 2004. Effects of post-teneral diet on foraging sucess of sterile male Mediterranean fruit flies. Entomologia Experimentalis et Applicata 110: 225-230.

Norry, F.M.; G.E. Calcagno; M.T. Vera; F. Manso \& J.C. Vilardi. 1999. Sexual selection on morphology independent of malemale competition in the Mediterranean fruit fly (Diptera: Tephritidae). Annals of the Entomological Society of America 92 (4): 571-577.

Papadopoulos, N.T.; B.I. Katsoyannos; N.A. Kouloussis; A.P. ECONOMOPOUlos \& J.R. CAREY. 1998. Effect of adult age, food, and time of day on sexual calling incidence of wild and mass-reared Ceratitis capitata males. Entomologia Experimentalis et Applicata 89: 175-182.

Papanastasiou, S.A.; A.D. Diamantidis; C.T. Nakas; J.R. Carey \& N.T. Papadopoulos. 2011. Dual reproductive cost of aging in male medflies: dramatic decrease in mating competitiveness and gradual reduction in mating performance. Journal of Insect Physiology 57: 1368-1374.

Pereira, R.; J. Sivinski \& P.E.A. Teal. 2009. Influence of methoprene and dietary protein on male Anastrepha suspensa (Diptera: Tephritidae) mating aggregations. Journal of Insect Physiology 55: 328-335.

Pereira, R; J. Sivinski \& P.E.A Teal. 2010. Influence of a juvenile hormone analog and dietary protein on male Anastrepha suspensa (Diptera: Tephritidae) sexual success. Journal of Economic Entomology 103: 40-46.

Pérez-Staples, D.; A.M.T. Harmer; S.R. Collins \& P.W. Taylor. 2008. Potential for prerelease diet supplements to increase the sexual performance and longevity of male Queensland fruit flies. Agricultural and Forest Entomology 10: 255-262.

Pérez-Staples, D.; C.W. Weldon; C. Smallridge \& P.W. Taylor. 2009. Prerelease feeding on yeast hydrolysate enhances sexual competitiveness of sterile male Queensland fruit flies in field cages. Entomologia Experimentalis et Applicata 131: 159-166.

Prokopy, R.J. \& J. Hendrichs. 1979. Mating behavior of Ceratitis capitata on a field-cage host tree. Annals of the Entomological Society of America 72: 642-648.

ProulX, S.R.; T. DAY \& L. Rowe. 2002: Older males signal more reliably. Proceedings of the Royal Society of London. Series B, Biological Sciences 269: 2291-2299.

Rodriguero, M.S.; J.C. Vilardi; M.T. Vera; J.P. Cayol \& E. Rial. 2002. Morphometric traits and sexual selection in medfly (Diptera: Tephritidae) under field cage conditions. Florida Entomologist 85: 143-149.

Shelly, T.E. \& S. Kennelly. 2002. Influence of male diet on male mating success and longevity and female remating in the Mediterranean fruit fly (Diptera: Tephritidae) under laboratory conditions. Florida Entomologist 85: 572-579.

Shelly, T.E. \& D.O. McInNIs. 2003. Influence of adult diet on the mating success and survival of male Mediterranean fruit flies (Diptera: Tephritidae) from two mass-rearing strains on field-caged host trees. Florida Entomologist 86: 340344.

SHelly, T.E.; J. Edu \& E. PAHIO. 2011. Female medflies mate selectively with young males but gain no apparent fitness benefits. Journal of Insect Behavior 24: 55-66.

Shelly, T.E.; S.S. KenNelly \& D.O. McInNis. 2002. Effect of adult diet on signaling activity, mate attraction, and mating success in male Mediterranean fruit flies (Diptera: Tephritidae). Florida Entomologist 85: 150-155.

Silva-Neto, A.M.; V.S. Dias \& I.S. Joachim-Bravo. 2009. Escolha de parceiro para acasalamento em Ceratitis capitata (Wiedemann) (Diptera: Tephritidae): influência do envelhecimento dos machos no sucesso de cópula. Neotropical Entomology 38 (5): 571-577.

Silva-Neto, A.M.; V.S. Dias \& I.S. Joachim-Bravo. 2012. Comportamento reprodutivo de Ceratitis capitata Wiedemann (Diptera: Tephritidae): efeito do tamanho dos machos sobre o seu sucesso de cópula. EntomoBrasilis 5 (3): 190-197.

Sivinski, J.; M. Aluja; G. Dodson; A. Freidberg; D. Headrick; K. Kaneshiro \& P. Landolf. 2001. Topics in the evolution of sexual behavior in the Tephritidae, p. 751-792. In: M. Aluja \& A. Norrbom (Eds). Fruit Flies (Tephritidae): Phylogeny and Evolution of Behavior. Boca Raton, CRC Press, 963p.

Slansky, F. \& J.M. Scriber. 1985. Food consumption and utilization, p. 89-163. In: G.A. Kerkut \& L.I. Gilbert (Eds). 
Comprehensive insect physiology, biochemistry and pharmacology. Oxford, Pergamon Press, 710 p.

TAYlor, P.W. \& B. Yuval. 1999. Postcopulatory sexual selection in Mediterranean fruit flies: advantages for large and proteinfed males. Animal Behavior 58: 247-254.

WARBURG, M.S. \& B. Yuval. 1996. Effects of energetic reserves on behavioral patterns of Mediterranean fruit flies. Oecologia 112: 314-319.

WhitTiER, T. S. \& K.Y. KANEShiro. 1995. Intersexual selection in the Mediterranean fruit fly: does female choice enhance fitness? Evolution 49: 990-996.

WhitTier, T.S.; K.Y. KANeShiro \& L.D. Prescot. 1992. Mating behavior of Mediterranean fruit flies (Diptera: Tephritidae) in a natural environment. Annals of the Entomological Society of America 85: 214-218.
WhitTier, T.S.; F.Y. NAN; T.E. Shelly \& K.Y. Kaneshiro. 1994. Male courtship success and female discrimination in the Mediterranean fruit fly (Diptera: Tephritidae). Journal of Insect Behavior 7: 159-170.

Yuval, B.; R. Kaspi; S.A. Field; S. Blay \& P. Taylor. 2002. Effects of post-teneral nutrition on reproductive success of male Mediterranean fruit flies (Diptera: Tephritidae). Florida Entomologist 85: 165-170.

Yuval, B.; K. Levy; R. Kaspi; P. TAYlor \& T. Shelly. 2007. Breakfast of champions or kiss of death? Survival and sexual performance of protein-fed, sterile Mediterranean fruit flies (Diptera: Tephritidae). Florida Entomologist 90 (1): 115-122.

Zucoloto, F.S. 1987. Feeding habits of Ceratitis capitata: Can larvae recognize a nutritional effective diet? Journal of Insect Physiology 33: 349-353.

Submitted: 27.VIII.2012; Accepted: 18.XII.2012.

Editorial responsibility: Carolina Arruda Freire 